\title{
Oceanisphaera ostreae sp. nov., isolated from seawater of an oyster farm, and emended description of the genus Oceanisphaera Romanenko et al. 2003
}

Correspondence Jung-Hoon Yoon jhyoon69@skku.edu

\author{
Won-Chan Choi, ${ }^{1}$ So-Jung Kang, ${ }^{1}$ Yong-Taek Jung, ${ }^{1}$ Tae-Kwang $\mathrm{Oh}^{1}$ \\ and Jung-Hoon Yoon ${ }^{1,2}$ \\ ${ }^{1}$ Korea Research Institute of Bioscience and Biotechnology (KRIBB), PO Box 115, Yusong, \\ Daejeon, South Korea \\ ${ }^{2}$ Department of Food Science and Biotechnology, Sungkyunkwan University, Jangan-gu, Suwon, \\ South Korea
}

\begin{abstract}
A Gram-stain-negative, motile, non-spore-forming and short rod- or rod-shaped bacterial strain, $\mathrm{T}-\mathrm{w} 6^{\top}$, was isolated from seawater of an oyster farm in the South Sea, Korea. Strain T-w6 ${ }^{\top}$ grew optimally at $25{ }^{\circ} \mathrm{C}$ and in the presence of $2 \%(\mathrm{w} / \mathrm{v}) \mathrm{NaCl}$. Phylogenetic analyses based on $16 \mathrm{~S}$ rRNA gene sequences revealed that strain $T-w 6^{\top}$ joined the cluster comprising Oceanisphaera species with a bootstrap resampling value of $90.8 \%$, and this cluster joined the clade comprising members of the genera Oceanimonas and Zobellella with a bootstrap resampling value of $100 \%$. Strain $\mathrm{T}-\mathrm{w} 6^{\top}$ exhibited $16 \mathrm{~S}$ rRNA gene sequence similarity of 95.9 and $96.6 \%$ to the type strains of Oceanisphaera litoralis and Oceanisphaera donghaensis, respectively. Strain $\mathrm{T}-\mathrm{w} 6^{\top}$ and the type strains of Oceanisphaera litoralis and Oceanisphaera donghaensis had Q-8 as the predominant ubiquinone and iso- $\mathrm{C}_{15: 0} 2-\mathrm{OH}$ and/or $\mathrm{C}_{16: 1} \omega 7 c, \mathrm{C}_{18: 1} \omega 7 c$ and $\mathrm{C}_{16: 0}$ as the major fatty acids. The major polar lipids were phosphatidylglycerol and phosphatidylethanolamine. The DNA G $+C$ content of strain T-w6 $6^{\top}$ was 56.6 mol\%. Mean DNA-DNA relatedness of strain $\mathrm{T}$-w6 $6^{\top}$ with Oceanisphaera litoralis DSM $15406^{\top}$ and Oceanisphaera donghaensis KCTC $12522^{\top}$ was 13 and $10 \%$, respectively. Phenotypic properties of strain $T-w 6^{\top}$ demonstrated that this strain could be distinguished from the other Oceanisphaera species. On the basis of the data presented, strain $T-w 6^{\top}$ is considered to represent a novel species of the genus Oceanisphaera, for which the name Oceanisphaera ostreae sp. nov. is proposed; the type strain is T-w6 ${ }^{\top}$ (=KCTC $23422^{\top}=$ CCUG $\left.60525^{\top}\right)$. An emended description of the genus Oceanisphaera is also presented.
\end{abstract}

The genus Oceanisphaera was first proposed by Romanenko et al. (2003), who described a single novel species, Oceanisphaera litoralis. Subsequently, another Oceanisphaera species, Oceanisphaera donghaensis, was described (Park et al., 2006). Phylogenetic analysis based on 16S rRNA gene sequences showed that the genus Oceanisphaera belongs to the Gammaproteobacteria (Romanenko et al., 2003). Members of the genus Oceanisphaera have been isolated from marine bottom sediments (Romanenko et al., 2003; Park et al., 2006). In this study, a bacterial strain, designated $\mathrm{T}-\mathrm{w} 6^{\mathrm{T}}$, which was isolated from seawater of an oyster farm on the southern coast of

The GenBank/EMBL/DDBJ accession number for the 16S rRNA gene sequence of strain $T-w 6^{\top}$ is H0340607.

Two supplementary figures are available with the online version of this paper.
Korea, is described. Comparative 16S rRNA gene sequence analysis indicated that, phylogenetically, strain $\mathrm{T}-\mathrm{w} 6^{\mathrm{T}}$ is affiliated with the genus Oceanisphaera. The aim of the present work was to determine the exact taxonomic position of strain $\mathrm{T}-\mathrm{w} 6^{\mathrm{T}}$ by using a polyphasic characterization that included the determination of chemotaxonomic and phenotypic properties and a detailed phylogenetic investigation based on $16 \mathrm{~S}$ rRNA gene sequences.

Strain T-w $6^{\mathrm{T}}$ was isolated by means of the standard dilution plating technique at $25{ }^{\circ} \mathrm{C}$ on marine agar 2216 (MA; Difco). The type strains of the two Oceanisphaera species were used as reference strains for phenotypic characterization, DNADNA hybridization and analyses of isoprenoid quinones and fatty acids. Oceanisphaera litoralis DSM $15406^{\mathrm{T}}$ was obtained from the Deutsche Sammlung von Mikroorganismen und Zellkulturen, Braunschweig, Germany, and Oceanisphaera 
donghaensis KCTC $12522^{\mathrm{T}}$ was obtained from the Korean Collection for Type Cultures, Daejeon, South Korea. Morphological, physiological and biochemical characteristics of strain $\mathrm{T}-\mathrm{w} 6^{\mathrm{T}}$ were investigated following routine cultivation on MA at $25^{\circ} \mathrm{C}$. Cell morphology was examined by light microscopy (E600; Nikon) and transmission electron microscopy (CM-20; Philips). Flagellation was determined by using transmission electron microscopy with cells from exponentially growing cultures. For this purpose, cells were negatively stained with $1 \%(\mathrm{w} / \mathrm{v})$ phosphotungstic acid and grids were examined after being air-dried. The Gram reaction was determined by using a commercial Gram stain kit (bioMérieux) according to the manufacturer's instructions. Endospores were investigated by using Schaeffer-Fulton (Murray et al., 1994) and malachite green (Smibert \& Krieg, 1994) staining methods. Growth in the absence of $\mathrm{NaCl}$ and in the presence of $0.5,1.0,2.0$ and $3.0 \%(\mathrm{w} / \mathrm{v}) \mathrm{NaCl}$ was investigated by using trypticase soy broth prepared according to the formula of the Difco medium except that $\mathrm{NaCl}$ was excluded. Growth at 2.0 $10.0 \%(\mathrm{w} / \mathrm{v}) \mathrm{NaCl}$ (in increments of $1.0 \%$ ) was investigated in marine broth 2216 (MB; Difco). Growth at 4, 10, 20, 25, 28, $30,37,40$ and $45^{\circ} \mathrm{C}$ was measured on $\mathrm{MA}$. The $\mathrm{pH}$ range for growth was determined in $\mathrm{MB}$ that was adjusted to $\mathrm{pH} 4.5$ 9.5 (in increments of $0.5 \mathrm{pH}$ units) by the addition of $\mathrm{HCl}$ or $\mathrm{Na}_{2} \mathrm{CO}_{3}$; the $\mathrm{pH}$ was verified after autoclaving. Growth under anaerobic conditions was determined after incubation in an anaerobic chamber (1029; Forma) on MA and on MA supplemented with potassium nitrate $(0.1 \%$, w/v), both of which had been prepared anaerobically under a nitrogen atmosphere $\left(\mathrm{N}_{2} / \mathrm{CO}_{2} / \mathrm{H}_{2}, 86: 7: 7\right)$. Catalase and oxidase activities were determined as described by Cowan \& Steel (1965). Hydrolysis of casein, starch, hypoxanthine, tyrosine and xanthine was tested on MA by using the substrate concentrations described by Cowan \& Steel (1965). Hydrolysis of aesculin, gelatin, Tweens 20,40,60 and 80 and urea and nitrate reduction were investigated as described previously (Lányí, 1987), with the modification that artificial seawater was used for preparation of media. The artificial seawater contained $\left(1^{-1}\right.$ distilled water) $23.6 \mathrm{~g} \mathrm{NaCl}, 0.64 \mathrm{~g}$ $\mathrm{KCl}, 4.53 \mathrm{~g} \mathrm{MgCl}_{2} .6 \mathrm{H}_{2} \mathrm{O}, 5.94 \mathrm{~g} \mathrm{MgSO}_{4} \cdot 7 \mathrm{H}_{2} \mathrm{O}$ and $1.3 \mathrm{~g}$ $\mathrm{CaCl}_{2} \cdot 2 \mathrm{H}_{2} \mathrm{O}$ (Bruns et al., 2001). Acid production from carbohydrates was determined as described by Leifson (1963). Utilization of substrates as sole carbon and energy sources was tested as described by Baumann \& Baumann (1981) using supplementation with $2 \%(\mathrm{v} / \mathrm{v})$ Hutner's mineral base (Cohen-Bazire et al., 1957) and $1 \%(\mathrm{v} / \mathrm{v})$ vitamin solution (Staley, 1968). Susceptibility to antibiotics was tested on MA plates using the following antibiotic discs: polymyxin B $(100 \mathrm{U})$, streptomycin $(50 \mu \mathrm{g})$, penicillin $\mathrm{G}(20 \mathrm{U})$, chloramphenicol $(100 \mu \mathrm{g})$, ampicillin $(10 \mu \mathrm{g})$, cephalothin $(30 \mu \mathrm{g})$, gentamicin $(30 \mu \mathrm{g})$, novobiocin $(5 \mu \mathrm{g})$, tetracycline $(30 \mu \mathrm{g})$, kanamycin $(30 \mu \mathrm{g})$, lincomycin $(15 \mu \mathrm{g})$, oleandomycin $(15 \mu \mathrm{g})$, neomycin $(30 \mu \mathrm{g})$ and carbenicillin $(100 \mu \mathrm{g})$. Enzyme activities were investigated using the API ZYM system (bioMérieux).

Cell biomass of strain T-w6 $6^{\mathrm{T}}$ for DNA extraction and for analyses of isoprenoid quinones and polar lipids was obtained from cultures grown for 3 days in $\mathrm{MB}$ at $25{ }^{\circ} \mathrm{C}$. Cell biomass of Oceanisphaera litoralis DSM $15406^{\mathrm{T}}$ and Oceanisphaera donghaensis KCTC $12522^{\mathrm{T}}$ for DNA extraction and isoprenoid quinone analysis was obtained from cultures grown under the same conditions. Chromosomal DNA was isolated and purified as described previously (Yoon et al., 1996), with the exception that RNase T1 was used in combination with RNase A to minimize contamination with RNA. The 16S rRNA gene was amplified by PCR using two universal primers as described previously (Yoon et al., 1998). Sequencing of the amplified 16S rRNA gene and phylogenetic analysis were performed as described by Yoon et al. (2003). Isoprenoid quinones were extracted according to the method of Komagata \& Suzuki (1987) and analysed using reversed-phase HPLC and a YMC ODS-A $(250 \times 4.6 \mathrm{~mm})$ column. For fatty acid methyl ester analysis, cell mass of strain $\mathrm{T}-\mathrm{w} 6^{\mathrm{T}}$, Oceanisphaera litoralis DSM $15406^{\mathrm{T}}$ and Oceanisphaera donghaensis KCTC $12522^{\mathrm{T}}$ was harvested from MA plates after incubation for 3 days at $25{ }^{\circ} \mathrm{C}$. Fatty acid methyl esters were extracted and prepared according to the standard protocol of the MIDI/Hewlett Packard Microbial Identification System (Sasser, 1990). Polar lipids were extracted in accordance with procedures described by Minnikin et al. (1984) and were identified by two-dimensional TLC followed by spraying with the appropriate detection reagents (Minnikin et al., 1984; Komagata \& Suzuki, 1987). The DNA G + C content was determined by the method of Tamaoka \& Komagata (1984), with the modification that DNA was hydrolysed and the resultant nucleotides were analysed by reversed-phase HPLC. DNA-DNA hybridization was performed fluorometrically by the method of Ezaki et al. (1989) using photobiotin-labelled DNA probes and microdilution wells. Hybridization was performed with five replications for each sample. The highest and lowest values obtained for each sample were excluded and the means of the remaining three values were quoted as DNA-DNA relatedness values.

Morphological, cultural, physiological and biochemical characteristics of strain $\mathrm{T}-\mathrm{w} 6^{\mathrm{T}}$ are given in the species description or in Table 1. The almost-complete 16S rRNA gene sequence of strain $\mathrm{T}-\mathrm{w} 6^{\mathrm{T}}$ determined in this study comprised $1465 \mathrm{nt}$ (approx. $96 \%$ of the Escherichia coli $16 \mathrm{~S}$ rRNA gene sequence). In the neighbour-joining phylogenetic tree based on $16 \mathrm{~S}$ rRNA gene sequences, strain T-w6 ${ }^{\mathrm{T}}$ joined the cluster comprising the type strains of the two Oceanisphaera species and one Oceanisphaera species with a name that has not been validly published by a bootstrap resampling value of $90.8 \%$ (Fig. 1). The cluster comprising strain $\mathrm{T}-\mathrm{w} 6^{\mathrm{T}}$ and members of the genus Oceanisphaera joined the cluster comprising members of the genera Oceanimonas and Zobellella with a bootstrap resampling value of $100 \%$ (Fig. 1). The relationship between strain T$\mathrm{w}^{\mathrm{T}}$ and the type strains of Oceanisphaera species was also maintained in trees constructed using the maximumlikelihood and maximum-parsimony algorithms (Fig. 1). Strain $\mathrm{T}-\mathrm{w} 6^{\mathrm{T}}$ exhibited $16 \mathrm{~S}$ rRNA gene sequence similarity of $95.9,96.6$ and $95.8 \%$ to the type strains of Oceanisphaera 
Table 1. Differential phenotypic characteristics of Oceanisphaera ostreae sp. nov. $\mathrm{T}^{\mathrm{w}} \mathrm{w} 6^{\top}$ and the type strains of the two Oceanisphaera species

Strains: 1, Oceanisphaera ostreae sp. nov. T-w6 ${ }^{\mathrm{T}}$ (data from this study); 2. Oceanisphaera litoralis DSM $15406^{\mathrm{T}}$; 3 , Oceanisphaera donghaensis KCTC $12522^{\mathrm{T}}$. All data are from this study except for Gram-staining, morphology, $\mathrm{NaCl}$ requirement for growth, growth at 4 and $40{ }^{\circ} \mathrm{C}$, catalase, oxidase, nitrate reduction, hydrolysis of substrates and DNA $\mathrm{G}+\mathrm{C}$ content of the reference strains, which are from Romanenko et al. (2003) and Park et al. (2006). +, Positive; -, negative; w, weakly positive. All strains are Gram-stain-negative. All strains are positive for motility, growth at $4{ }^{\circ} \mathrm{C}$, catalase, oxidase, nitrate reduction, utilization of acetate, succinate and pyruvate, activity of alkaline phosphatase and leucine arylamidase and susceptibility to chloramphenicol, gentamicin, neomycin and polymyxin B. All strains are negative for hydrolysis of aesculin and gelatin, utilization of $\mathrm{L}$-arabinose, cellobiose, formate, Dgalactose, D-glucose, L-glutamate, maltose, D-mannose, salicin, sucrose, trehalose and D-xylose, activity of esterase lipase (C4), lipase (C14), valine arylamidase, cystine arylamidase, trypsin, $\alpha$-chymotrypsin, acid phosphatase, naphthol-AS-BI-phosphohydrolase, $\alpha$-galactosidase, $\beta$ galactosidase, $\beta$-glucuronidase, $\alpha$-glucosidase, $\beta$-glucosidase, $N$-acetyl$\beta$-glucosaminidase, $\alpha$-mannosidase and $\alpha$-fucosidase, and susceptibility to ampicillin, lincomycin, novobiocin, oleandomycin, penicillin $\mathrm{G}$ and tetracycline.

\begin{tabular}{|lccc|}
\hline Characteristic & $\mathbf{1}$ & $\mathbf{2}$ & $\mathbf{3}$ \\
\hline Cell morphology & Short rods or rods & Cocci & Cocci \\
NaCl requirement for growth & - & + & + \\
Growth at $40{ }^{\circ} \mathrm{C}$ & - & + & + \\
Urea hydrolysis & + & + & - \\
Utilization of: & & & \\
$\quad$ D-Fructose & - & + & - \\
Citrate & - & + & - \\
Benzoate & - & + & - \\
L-Malate & + & + & - \\
Esterase (C8) activity (API & - & - & W \\
ZYM) & & & \\
Susceptibility to antibiotics & & & \\
Carbenicillin & - & W & - \\
Cephalothin & - & - & W \\
Kanamycin & + & - & + \\
Streptomycin & + & - & - \\
DNA G+C content (mol\%) & 56.6 & 56.4 & 56.6 \\
\hline
\end{tabular}

litoralis and Oceanisphaera donghaensis and 'Oceanisphaera arctica' V1-41, respectively. It exhibited 16S rRNA gene sequence similarity of $94.3-96.4 \%$ to members of the genera Oceanimonas and Zobellella and less than $92.1 \%$ similarity to strains of other species used in the phylogenetic analysis.

The predominant isoprenoid quinone detected in strain $\mathrm{T}$ $\mathrm{w}^{\mathrm{T}}$ was ubiquinone-8 (Q-8). In this study, the type strains of Oceanisphaera litoralis and Oceanisphaera donghaensis also had Q-8 as the predominant isoprenoid quinone. The cellular fatty acid profiles of strain $\mathrm{T}-\mathrm{w} 6^{\mathrm{T}}$ and the type strains of two Oceanisphaera species analysed in this study are shown in Table 2 . The major fatty acids ( $>10 \%$ of total

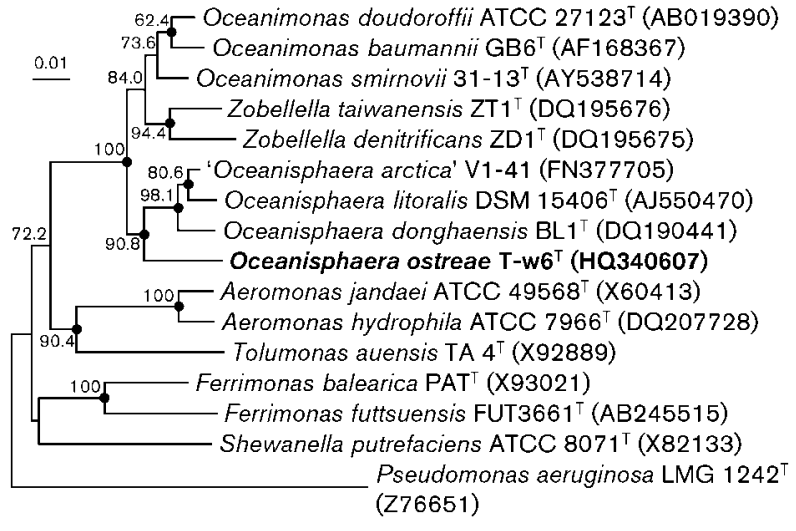

Fig. 1. Neighbour-joining phylogenetic tree based on 16S rRNA gene sequences showing the positions of Oceanisphaera ostreae sp. nov. $T-w 6^{\top}$, other Oceanisphaera species and some other related taxa. Bootstrap values (expressed as percentages of 1000 replications) $>50 \%$ are shown at branching points. Filled circles indicate that the corresponding nodes were also recovered in trees generated with the maximum-likelihood and maximum-parsimony algorithms. Pseudomonas aeruginosa LMG $1242^{\top}$ was used as an outgroup. Bar, 0.01 substitutions per nucleotide position.

fatty acids) found in strain $\mathrm{T}-\mathrm{w} 6^{\mathrm{T}}$ were iso- $\mathrm{C}_{15: 0} 2-\mathrm{OH}$ and/or $\mathrm{C}_{16: 1} \omega 7 c, \mathrm{C}_{18: 1} \omega 7 c$ and $\mathrm{C}_{16: 0}$ (Table 2). The fatty acid profiles were similar in all strains, although there were differences in the proportions of some fatty acids (Table 2). The major polar lipids detected in strain $\mathrm{T}-\mathrm{w} 6^{\mathrm{T}}$ were phosphatidylglycerol and phosphatidylethanolamine; a minor amount of diphosphatidylglycerol was also present (Supplementary Fig. S1, available in IJSEM Online). This polar lipid profile was the same as those of the type strains of Oceanisphaera litoralis and Oceanisphaera donghaensis (Romanenko et al., 2003; Park et al., 2006). The DNA $\mathrm{G}+\mathrm{C}$ content of strain $\mathrm{T}-\mathrm{w} 6^{\mathrm{T}}$ was $56.6 \mathrm{~mol} \%$. Hence, it is appropriate to classify strain $\mathrm{T}-\mathrm{w} 6^{\mathrm{T}}$ as a member of the genus Oceanisphaera based on the absence of chemotaxonomic differences between strain $\mathrm{T}-\mathrm{w} 6^{\mathrm{T}}$ and Oceanisphaera species, as well as the phylogenetic data based on $16 \mathrm{~S}$ rRNA gene sequences.

Strain $\mathrm{T}-\mathrm{w} 6^{\mathrm{T}}$ exhibited mean DNA-DNA relatedness of 13 and $10 \%$ to Oceanisphaera litoralis DSM $15406^{\mathrm{T}}$ and Oceanisphaera donghaensis KCTC $12522^{\mathrm{T}}$, respectively. Strain T-w $6^{\mathrm{T}}$ could be distinguished from Oceanisphaera litoralis and Oceanisphaera donghaensis by several phenotypic characteristics, most of which were determined under the same conditions and by the same methods (Table 1). The phylogenetic and genetic distinctiveness and differential phenotypic properties of strain $\mathrm{T}-\mathrm{w} 6^{\mathrm{T}}$ are sufficient to show that this strain is separate from other Oceanisphaera species (Stackebrandt \& Goebel, 1994). Therefore, on the basis of the phenotypic, chemotaxonomic, phylogenetic and genetic data, strain $\mathrm{T}-\mathrm{w} 6^{\mathrm{T}}$ is considered to represent a novel species of the genus Oceanisphaera, for which the name Oceanisphaera ostreae sp. nov. is proposed. 
Table 2. Cellular fatty acid compositions of Oceanisphaera ostreae sp. nov. $\mathrm{T}-\mathrm{w} 6^{\top}$ and the type strains of the two Oceanisphaera species

Strains: 1, Oceanisphaera ostreae $\mathrm{T}-\mathrm{w} 6^{\mathrm{T}} ; 2$. Oceanisphaera litoralis DSM $15406^{\mathrm{T}} ; 3$, Oceanisphaera donghaensis KCTC $12522^{\mathrm{T}}$. All data are from this study. Values are percentages of total fatty acids. Fatty acids that represent $<0.5 \%$ in all strains were omitted. - , Not detected; ECL, equivalent chain length.

\begin{tabular}{|c|c|c|c|}
\hline Fatty acid & 1 & 2 & 3 \\
\hline \multicolumn{4}{|c|}{ Straight-chain } \\
\hline $\mathrm{C}_{12: 0}$ & 7.1 & 6.5 & 6.4 \\
\hline $\mathrm{C}_{14: 0}$ & 1.2 & 0.3 & 0.4 \\
\hline $\mathrm{C}_{15: 0}$ & 1.0 & 0.7 & 1.0 \\
\hline $\mathrm{C}_{16: 0}$ & 15.6 & 20.4 & 20.6 \\
\hline $\mathrm{C}_{17: 0}$ & 0.6 & 0.4 & 0.3 \\
\hline \multicolumn{4}{|l|}{ Branched } \\
\hline iso- $\mathrm{C}_{16: 0}$ & - & 1.2 & 1.7 \\
\hline iso- $\mathrm{C}_{17: 0}$ & - & - & 0.7 \\
\hline \multicolumn{4}{|l|}{ Unsaturated } \\
\hline $\mathrm{C}_{17: 1} \omega 8 c$ & 1.0 & 0.4 & 0.3 \\
\hline $\mathrm{C}_{18: 1} \omega 7 c$ & 21.7 & 22.3 & 17.6 \\
\hline \multicolumn{4}{|l|}{ Unknown } \\
\hline ECL 14.502 & 1.0 & 0.5 & 0.5 \\
\hline \multicolumn{4}{|c|}{ Summed features ${ }^{\star}$} \\
\hline 2 & 5.9 & 5.4 & 5.7 \\
\hline 3 & 43.7 & 40.7 & 42.3 \\
\hline
\end{tabular}

${ }^{\star}$ Summed features represent groups of two or three fatty acids that cannot be separated by GLC with the MIDI system. Summed feature 2 contained $\mathrm{C}_{14: 0} 3-\mathrm{OH}$ and/or iso- $\mathrm{C}_{16: 1}$. Summed feature 3 contained iso- $\mathrm{C}_{15: 0} 2-\mathrm{OH}$ and/or $\mathrm{C}_{16: 1} \omega 7 c$.

\section{Emended description of the genus Oceanisphaera Romanenko et al. 2003}

The description of the genus Oceanisphaera is as given by Romanenko et al. (2003) with the following amendments. Cells are cocci, short rods or rods. The predominant ubiquinone is Q-8.

\section{Description of Oceanisphaera ostreae sp. nov.}

Oceanisphaera ostreae (os.tre' a.e. L. gen. n. ostreae of/from an oyster).

Cells are Gram-stain-negative, non-spore-forming and short rods or rods $(0.5-1.0 \times 1.2-5.0 \mu \mathrm{m})$. Motile by means of a single polar flagellum (Supplementary Fig. S2). Colonies on MA are circular to slightly irregular, slightly convex, smooth, glistening, light greyish yellow and $1.0-1.5 \mathrm{~mm}$ in diameter after incubation for 3 days at $25^{\circ} \mathrm{C}$. Optimal growth occurs at $25{ }^{\circ} \mathrm{C}$; grows at 4 and $37{ }^{\circ} \mathrm{C}$, but not at $40{ }^{\circ} \mathrm{C}$. Optimal pH for growth is between 7.0 and 8.0; grows at $\mathrm{pH}$ 5.0, but not at $\mathrm{pH} 4.5$. Optimal growth occurs in the presence of $2 \%$ (w/v) $\mathrm{NaCl}$; grows in $0-10.0 \%(\mathrm{w} / \mathrm{v}) \mathrm{NaCl}$. Growth does not occur under anaerobic conditions on MA or on MA supplemented with nitrate. Hypoxanthine, xanthine, tyrosine and Tweens 20, 40, 60 and 80 are hydrolysed, but casein and starch are not. Acid is produced from D-ribose, but not from L-arabinose, cellobiose, D-fructose, D-galactose, D-glucose, myo-inositol, lactose, maltose, D-mannitol, Dmannose, melezitose, melibiose, raffinose, L-rhamnose, Dsorbitol, sucrose, trehalose or $\mathrm{D}$-xylose. The predominant ubiquinone is Q-8. The major fatty acids $(>10 \%$ of total fatty acids) are iso- $\mathrm{C}_{15: 0} 2-\mathrm{OH}$ and/or $\mathrm{C}_{16: 1} \omega 7 c, \mathrm{C}_{18: 1} \omega 7 c$ and $\mathrm{C}_{16: 0}$. The major polar lipids are phosphatidylglycerol and phosphatidylethanolamine; diphosphatidylglycerol is present as a minor component. Other phenotypic properties are shown in Table 1.

The type strain is T- $6^{\mathrm{T}}\left(=\mathrm{KCTC} 23422^{\mathrm{T}}=\mathrm{CCUG} 60525^{\mathrm{T}}\right.$ ), isolated from seawater of an oyster farm in the South Sea, Korea. The DNA G+C content of the type strain is $56.6 \mathrm{~mol} \%$ (HPLC).

\section{Acknowledgements}

This work was supported by the 21C Frontier Program of Microbial Genomics and Applications from the Ministry of Education, Science and Technology (MEST) of the Republic of Korea (grant 11-2008-00002-00).

\section{References}

Baumann, P. \& Baumann, L. (1981). The marine Gram-negative eubacteria: genera Photobacterium, Beneckea, Alteromonas, Pseudomonas, and Alcaligenes. In The Prokaryotes, pp. 1302-1331. Edited by M. P. Starr, H. Stolp, H. G. Trüper, A. Balows \& H. G. Schlegel. Berlin: Springer.

Bruns, A., Rohde, M. \& Berthe-Corti, L. (2001). Muricauda ruestringensis gen. nov., sp. nov., a facultatively anaerobic, appendaged bacterium from German North Sea intertidal sediment. Int J Syst Evol Microbiol 51, 1997-2006.

Cohen-Bazire, G., Sistrom, W. R. \& Stanier, R. Y. (1957). Kinetic studies of pigment synthesis by non-sulfur purple bacteria. J Cell Comp Physiol 49, 25-68.

Cowan, S. T. \& Steel, K. J. (1965). Manual for the Identification of Medical Bacteria. London: Cambridge University Press.

Ezaki, T., Hashimoto, Y. \& Yabuuchi, E. (1989). Fluorometric deoxyribonucleic acid-deoxyribonucleic acid hybridization in microdilution wells as an alternative to membrane filter hybridization in which radioisotopes are used to determine genetic relatedness among bacterial strains. Int J Syst Bacteriol 39, 224-229.

Komagata, K. \& Suzuki, K. (1987). Lipid and cell-wall analysis in bacterial systematics. Methods Microbiol 19, 161-207.

Lányí, B. (1987). Classical and rapid identification methods for medically important bacteria. Methods Microbiol 19, 1-67.

Leifson, E. (1963). Determination of carbohydrate metabolism of marine bacteria. J Bacteriol 85, 1183-1184.

Minnikin, D. E., O’Donnell, A. G., Goodfellow, M., Alderson, G., Athalye, M., Schaal, A. \& Parlett, J. H. (1984). An integrated procedure for the extraction of bacterial isoprenoid quinones and polar lipids. J Microbiol Methods 2, 233-241.

Murray, R. G. E., Doetsch, R. N. \& Robinow, F. (1994). Determinative and cytological light microscopy. In Methods for General and Molecular Bacteriology, pp. 21-41. Edited by P. Gerhardt, R. G. E. Murray, 
W. A. Wood \& N. R. Krieg. Washington, DC: American Society for Microbiology.

Park, S.-J., Kang, C.-H., Nam, Y.-D., Bae, J.-W., Park, Y.-H., Quan, Z.-X., Moon, D.-S., Kim, H.-J., Roh, D.-H. \& Rhee, S.-K. (2006). Oceanisphaera donghaensis sp. nov., a halophilic bacterium from the East Sea, Korea. Int J Syst Evol Microbiol 56, 895-898.

Romanenko, L. A., Schumann, P., Zhukova, N. V., Rohde, M., Mikhailov, V. V. \& Stackebrandt, E. (2003). Oceanisphaera litoralis gen. nov., sp. nov., a novel halophilic bacterium from marine bottom sediments. Int J Syst Evol Microbiol 53, 1885-1888.

Sasser, M. (1990). Identification of bacteria by gas chromatography of cellular fatty acids, MIDI Technical Note 101. Newark, DE: MIDI Inc.

Smibert, R. M. \& Krieg, N. R. (1994). Phenotypic characterization. In Methods for General and Molecular Bacteriology, pp. 607-654. Edited by P. Gerhardt, R. G. E. Murray, W. A. Wood \& N. R. Krieg. Washington, DC: American Society for Microbiology.

Stackebrandt, E. \& Goebel, B. M. (1994). Taxonomic note: a place for DNA-DNA reassociation and $16 \mathrm{~S}$ rRNA sequence analysis in the present species definition in bacteriology. Int J Syst Bacteriol 44, 846849.

Staley, J. T. (1968). Prosthecomicrobium and Ancalomicrobium: new prosthecate freshwater bacteria. J Bacteriol 95, 1921-1942.

Tamaoka, J. \& Komagata, K. (1984). Determination of DNA base composition by reversed-phase high-performance liquid chromatography. FEMS Microbiol Lett 25, 125-128.

Yoon, J.-H., Kim, H., Kim, S.-B., Kim, H.-J., Kim, W. Y., Lee, S. T., Goodfellow, M. \& Park, Y.-H. (1996). Identification of Saccharomonospora strains by the use of genomic DNA fragments and rRNA gene probes. Int J Syst Bacteriol 46, 502-505.

Yoon, J.-H., Lee, S. T. \& Park, Y.-H. (1998). Inter- and intraspecific phylogenetic analysis of the genus Nocardioides and related taxa based on $16 \mathrm{~S}$ rDNA sequences. Int $J$ Syst Bacteriol 48, 187194.

Yoon, J.-H., Kim, I.-G., Shin, D.-Y., Kang, K. H. \& Park, Y.-H. (2003). Microbulbifer salipaludis sp. nov., a moderate halophile isolated from a Korean salt marsh. Int J Syst Evol Microbiol 53, 53-57. 